Annals of Warsaw University of Life Sciences - SGGW

Land Reclamation No 46 (3), 2014: 221-232

(Ann. Warsaw Univ. of Life Sci. - SGGW, Land Reclam. 46 (3), 2014)

\title{
The graphic method of sizing pipe reservoir for short, high-intensity rainfalls
}

\author{
BARTOSZ SZELĄG ${ }^{1}$, ADAM KICZKO ${ }^{2}$ \\ ${ }^{1}$ Department of Geotechnics and Water Engineering, Kielce University of Technology \\ ${ }^{2}$ Division of Hydraulics, Warsaw University of Life Sciences - SGGW
}

\begin{abstract}
The graphic method of sizing pipe reservoir for short, high-intensity rainfalls. The sizing of a storage reservoir, in order to reduce maximum water discharges in stormwater drainage systems, is one of the major topics in the civil engineering. In this article a methodology that allows identifying an optimal capacity of a pipe reservoir is proposed. Applying a simplified water flow model it was possible to bind various reservoir's parameters (a reservoir diameter, a diameter of an outflow orifice and an outflow coefficient) with an inflow hydrograph (a peak flow, a time of rising, a hydrograph fineness, a maximum discharge and a total volume). On the basis of functional relationships the nomographs were elaborated, allowing determining a desirable size of the reservoir, in a sense of a required peak reduction. The usage of the proposed methodology is presented with a simple example.
\end{abstract}

Key words: short, high-intensity rainfalls, pipe reservoir, volume reservoir, linear drainage system

\section{INTRODUCTION}

The development of urban agglomerations and the aging of the existing stormwater collection systems lead to numerous stormwater drainage problems. They include the increasingly common flooding of catchments, which often causes traffic paralysis and financial losses. In order to avoid the above, it is justifiable to build detention reservoirs temporarily capturing a certain amount of the hydrograph volume, resulting in the maximum flows being reduced and delayed. However, due to a strong degree of urbanization of an area, allocating a site for such structures may be significantly impeded. Although the last twenty years have seen an advancement in the relief reservoir construction (Mrowiec 2002, 2007, Kisiel et al. 2008), the required surface area necessary for the construction of a rectangular reservoir may render it impossible for such a reservoir to be located at a given point of the drainage system. In these circumstances, tanks made from polyethylene or fibreglass tubes with large diameters may provide an alternative solution, as the space required for building a tubular tank in a highly urbanized city area becomes significantly reduced, which is very important in engineering practice.

The methodology of a rectangular reservoir sizing is well developed, as it is reflected in a number of graphical methods of calculating its storage volume, taking into account different outlet control devices - orifice, weir (Akan 1990, McEnroe 1992, Gomez et al. 2001, Graber 2009).

In numerous works (Venutelli 2004, Aldrighetti 2007, Szydłowski and Michalińska-Murawska 2012) devoted to the issue of the fluid flow through the circular pipe, appropriate numerical 
algorithms are applied to solve differential equations for momentum and mass conservation. Still, there is relatively little information on the subject of waste water accumulation in pipe reservoirs. One exception are the works of Mrowiec (2002), who made a physical model of the reservoir, providing the basis for the calibration of mathematical models FLUENT and SWMM (Mrowiec 2002, 2007). The scope of work undertaken by Mrowiec did not include the development of a graphic method of sizing a storage reservoir.

Basically, in order to determine the storage volume of a detention reservoir it is necessary to solve complex sets of differential equations using numerical methods. Therefore, simplified solutions such as Baker's method (1979), or the equations presented in the guidelines of SCS (1986) prepared for the rainfalls of type I, II and III are very popular in practice. These methods capture the relation between the dimensionless reservoir volume and the maximum flow reduction coefficient and the inflow hydrograph volume. The conducted theoretical analyses (Graber 2009, Hong 2009) concerning the reservoir volume sizing reveal that Baker's method results in the reservoir oversizing and the SCS method in its undersizing.

Still, there is no reliable technique of sizing pipe reservoirs. With this in mind, it is advisable to develop a universal method of designing a reservoir diameter that would not require solving complex differential equations or applying the appropriate necessary software. Moreover, it is essential to verify the reservoir design methods which can potentially be used in determining the necessary storage volume of the pipe reservoir. This paper presents a method for the development of nomographs showing a relation between the triangular inflow hydrograph parameters and the dimensions of a reservoir equipped with a circular orifice on the outflow. The preparation of nomographs involved the application of results (the storage reservoir length) of numerical calculations of a differential equation for the storage capacity volume.

The article contains an example of the application of the nonograph to size a pipe reservoir for the adopted shape and volume of the inflow hydrograph.

\section{MATERIAL AND METHODS}

\section{Sizing pipe reservoir volume}

Surface runoff is a very complex phenomenon and the fact that it depends on numerous factors (Zawilski and Osuch-Pajdzińska 1998a, 1998b, Dayarante and Perera 2004, 2008, Shuster et al. 2005, Gironàs et al. 2009, Sikorska and Banasik 2012) makes it impossible to take them all into account while applying simple engineering methods. For this reason a problem is simplified by the use of a parametric relationship to describe the outflow hydrographs. The reviewed literature reveals that the following hydrograph's function are adopted for calculating the reservoir storage volume: triangular ones (Basha 1995, Gomez et al. 2001, Hong 2009), trapezoid ones (Burton 1980, Donahue and McCuen 1981, Guo 1999, Graber 2009), described by the gamma likelihood density function (Kessler and Diskin 1991, McEnroe 1992, Currey and Akan 1998), with 
a curvilinear graph $Q=f(t)$ in the SCS method (1986). The developed graphic-analytic methods (Guo 2004) have a universal character, so a hydrograph of any shape can be adopted on the inflow to the reservoir.

In the presented analyses a triangular form of the inflow hydrograph was chosen. As demonstrated by the following works (ATV A - 118 1990, Hong et al. 2006, Hong 2009) dealing with the subject of the research, such a form is a proper representation of the catchment's response to a short, high-intensity rainfall. The application of this type of parametrization for illustrating the intensity of the inflowing and outflowing water in reservoir sizing is discussed by i.a. Guo (1999). A triangular hydrograph of the inflow (Fig. 1) to the reservoir in the rise and recession phases, respectively, can be expressed with a formula:

$$
I(t)=\frac{I_{\max }}{t_{p}} \cdot t
$$

$I(t)=I_{\max } \cdot\left(1+\frac{1}{\lambda}-\frac{t}{\lambda \cdot t_{p}}\right)$

in which:

$I_{\text {max }}$ - peak flow,

$t_{p}$ - time of rising,

$\lambda$ - hydrograph fineness expressed as $t_{\text {op }} / t_{p}$.

Taking into consideration the hydrograph fineness $(\lambda)$, the inflow hydrograph volume can be expressed as follows:

$V_{c}=\frac{1}{2} \cdot I_{\max } \cdot t_{p} \cdot(\lambda+1)$

where:

$I_{\max }, t_{p}, \lambda$ - as in formulas (1) and (2).

Figure 1 shows the above relations.

\section{The volume balance equation}

The methods of designing storage reservoir are based on a principle applied in hydrology, i.e. the comparison of the inflow and outflow variables graphs. The first solution involves determin-

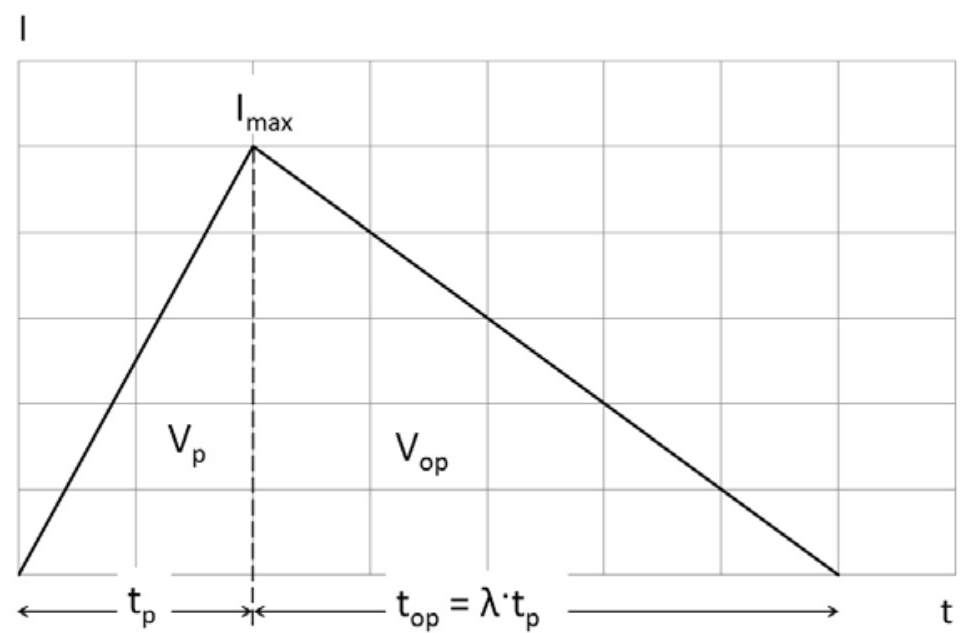

FIGURE 1. The inflow hydrograph adopted for calculating the storage tank volume 
ing the surface area of a figure formed by the inflow and outflow hydrographs, the second one is the modification of the first one and involves plotting inflow and outflow cumulative curves. In both cases the relation between the variability in the volume of stormwater accumulated in the basin $V(t)$ and the intensity of the inflow $I(t)$ and the outflow of discharge devices $O(h)$ is expressed with the differential equation for the volume balance in the following form:

$I(t)-O(h)=\frac{\mathrm{d} V}{\mathrm{~d} t}$

in which:

$I(t)$ - inflow to the reservoir, $O(h)$ - outflow from the reservoir with the filling $h$,

$\mathrm{d} V$ - stormwater volume change in the reservoir in time $\mathrm{d} t$.

Mrowiec (2007) studied in detail the variability of the surface area of the water level in respect of a volume in different stages of filling and emptying of the pipe reservoir (Fig. 2). Due to the complexity of the problem, a longitudinal slope of the accumulation chamber $i=0$ was adopted (a task where $i \neq 0$ will be discussed in a separate analysis). Consequently, the reservoir volume $V(h)$ for a filling $h$ can be expressed as follows:

$V(h)=A(h) \cdot L_{z b}$

where:

$A(h)$ - surface area of the wetted surface for the accumulation chamber filling $h$, $L_{z b}$ - the length of the storage reservoir.

Surface area $A(h)$ is expressed as follows:

$A(h)=\frac{D_{a k}^{2}}{8} \cdot[2 \cdot \theta(h)-\sin 2 \cdot \theta(h)]$

where:

$D_{a k}$ - storage reservoir diameter (m),

$\theta$ - the central angle in the radians corresponding to the filling $h$, equal $\theta=\arccos \left(1-\frac{2 \cdot h}{D}\right)$

In the above analyses, due to the complexity of its form, equation (6) was approximated by Hager's relation (2010) as:

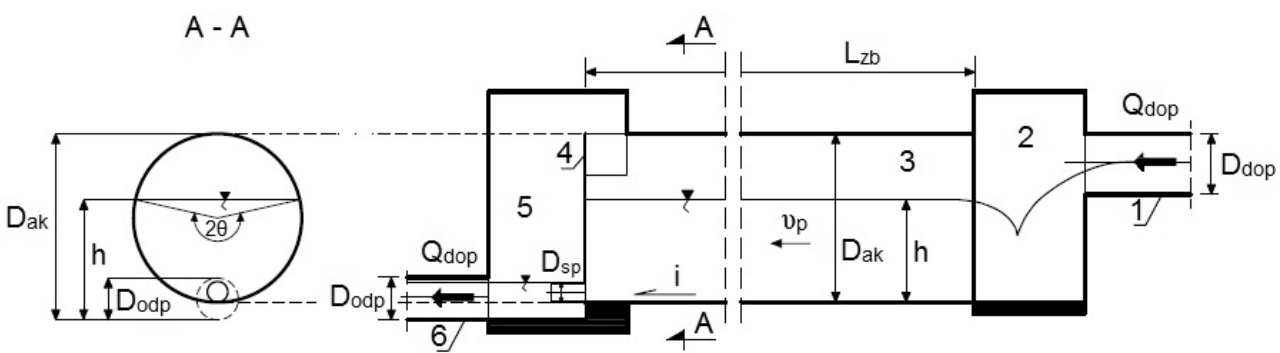

where: $D_{a k}$ - the reservoir's diameter, $L_{z b}$ - the reservoir's length, $D_{s p}-$ the diameter of the reservoir orifice, $\mathrm{D}_{\text {dop }}$ - the diameter of the inflow channel, $\mathrm{D}_{\text {odp }}$ - the diameter of the outflow channel, $\mathrm{h}$ - the accumulation chamber filling, $\mathrm{i}-\mathrm{a}$ the longitudinal slope of the pipe reservoir, $\mathrm{v}_{\mathrm{p}}$ - the average velocity of stormwater flow in the pipe reservoir, $Q_{\text {dop }}$ - inflow to reservoir, $Q_{\text {odp }}$ - outflow from reservoir. 1 - inflow channel, 2 - inlet chamber, 3 - detention pipe (accumulation chamber), 4 - overflow weir, 5 - outlet chamber.

FIGURE 2. Pipe reservoir diagram 
where:

$A(h)$ - surface area of the cross section of the pipe reservoir,

$h$ - water depth $\left(h_{\max }=h_{m}=D_{a k}\right)$.

The filling of the pipe reservoir which accumulates the storage volume $V(h)$ can be determined by substituting formula (7) into equation (6) and performing appropriate transformations:

$h=\left(\frac{V(h)}{D_{a k}^{0.60} \cdot L_{z b}}\right)^{0.71}$

where:

$L_{z b}, D_{a k}, V(h)$ - defined as in formulas (5) and (6).

The outflow from the pipe reservoir through a circular orifice can be defined as follows:

$$
O(h)=C_{s p} \sqrt{h}
$$

where:

$C_{s p}$ - parameter taking into account the characteristics of an orifice, expressed as $C_{s p}=\frac{1}{4} \mu \cdot \pi \cdot D_{s p}{ }^{2} \cdot(2 g)^{0.5}(\mu-$ out-

flow coefficient, $g$ - gravitational acceleration, $D_{s p}-$ circular orfice diameter).

Substituting formula (8) into equation (9) one obtains:

$O(h)=C_{s p} \cdot\left(\frac{V(h)}{C_{z}}\right)^{0.36}$

where:

$C_{s p}$ - parameter defining the characteristics of the orifice,

$V(h)$ - volume of the pipe reservoir with the filling $h$,

$C_{z}$ - parameter determined as $C_{z}=$ $=L_{z b} \cdot D_{a k}{ }^{0.60}$.
Assuming that the reservoir volume is chosen in such a way that the outflow is merely a function of the water depth, with the reservoir being filled completely, the maximum intensity of the outflow through the orifice is:

$O\left(h=D_{a k}\right)=C_{s p} \cdot \sqrt{D_{a k}}$

and consequently the maximum flow reduction coefficient equals:

$\beta=\frac{O\left(h=D_{a k}\right)}{I_{\max }}=\frac{C_{s p} \cdot \sqrt{D_{a k}}}{I_{\max }}$

where:

$C_{s p}, D_{a k}, I_{\max }-$ defined as in formulas (1), (2), (6), and (9).

The differential equation for $V(h)$ was solved using the Runge-Kutta method in the explicit form with regard to the length of the reservoir pipe $\left(L_{z b}\right)$. This yielded the model defining the inflow-outflow transformation, which is the function of the reservoir length $\left(L_{z b}\right)$. This brings the issue of the reservoir sizing to the identification of the variable length value at which a specified reduction effect is achieved. This constraint was introduced in the form of the minimization problem, performed using the Nelder-Mead local optimization algorithm (1965). The minimized objective function had the following form:

$F=\left(\beta_{\mathrm{c}}-\beta_{\mathrm{o}}\right)^{2}$

where:

$\beta_{\mathrm{c}}-$ reduction set point,

$\beta_{\mathrm{o}}$-reduction value calculated on the basis

of the numerical solution of equation (4). 
Thus the sizing problem had the following form:

$$
L_{\text {opt }}=\operatorname{argmin} F(L)
$$

where:

$L_{\text {opt }}$ - length of the reservoir for which the objective function reaches the minimum value.

In order to ensure appropriate accuracy of the solution, understood as the fulfilment of the condition:

$F\left(L_{\text {opt }}\right) \approx 0$

it was necessary to apply a multiple execution of the minimization algorithm for different localization of the starting point from which the search for the optimum position begins. This procedure prevented stopping the minimization within the objective function local minimum. Because of the implicit form of the problem with regard to the length, it was necessary to introduce an additional condition defining the outflow in the state of complete filling. It took the form of the assumption about the lack of retention in the network above the reservoir, resulting in equalization of inflow and outflow for $h=D_{a k}$. The inflow hydrograph parameters were set point values in the minimization problem. Thus, the analysis of the relations between particular parameters required a multiple execution of this problem.

\section{Dimensionless volume balance}

The generalization of the results is possible by identifying the dependencies between the dimensionless variables, connecting the inflow hydrograph parameters to the characteristics of the reservoir being sized. This was achieved on the basis of dimensionless equations of state. Substituting formulas (1), (2) and (10) respectively into (4) gave the following dynamics of the volume balance in pipe reservoir in the rise and recession phases:

$$
\begin{aligned}
& \frac{\mathrm{d} V}{\mathrm{~d} t}=I_{\max } \cdot \frac{t}{t_{p}}-C_{s p} \cdot\left(\frac{V}{C_{z}}\right)^{0.35} \\
& \frac{\mathrm{d} V}{\mathrm{~d} t}=I_{\max } \cdot\left(1+\frac{1}{\lambda}-\frac{t}{\lambda \cdot t_{p}}\right)-C_{s p} \cdot\left(\frac{V}{C_{z}}\right)^{0.35}
\end{aligned}
$$

The above equations (16) and (17) can be converted into a dimensionless form by introducing the following parameters (Akan 1990, McEnroe 1990, Hong 2009):

- dimensionless time from the begin$\operatorname{ning}\left(t^{*}\right)$

$$
t^{*}=\frac{t}{t_{p}}
$$

- dimensionless inflow $\left(I^{*}\right)$

$$
I^{*}=\frac{I}{I_{\max }}
$$

- dimensionless reservoir volume $\left(V^{*}\right)$

$$
V^{*}=\frac{V}{V_{c}}
$$

where:

$t_{p}$ - the rise phase time,

$I_{\max }-$ peak flow,

$V_{c}$-inflow hydrograph volume.

Substituting the formulas (18), (19) and (20) into (16) and (17) gave the following dimensionless equations: 


$$
\begin{aligned}
& \frac{\mathrm{d} V^{*}}{\mathrm{~d} t^{*}}=\omega \cdot t^{*}-\kappa_{D} \cdot\left(V^{*}\right)^{0.35} \\
& \frac{\mathrm{d} V^{*}}{\mathrm{~d} t^{*}}=\omega \cdot\left(1+\frac{1}{\lambda}-\frac{t^{*}}{\lambda}\right)-\kappa_{D} \cdot\left(V^{*}\right)^{0.35}
\end{aligned}
$$

in which:

$\kappa_{D}$ - parameter taking into account the characteristics of the reservoir and the inflow hydrograph was expressed as follows:

$\kappa_{D}=\frac{C_{s p} \cdot t_{p}}{C_{z}^{0.35} \cdot V_{c}^{0.65}}$

in which:

$\omega$ - the inflow hydrograph shape parameter defined with the formula:

$\omega=\frac{I_{\max } \cdot t_{p}}{V_{c}}$

The volumes of the pipe reservoirs were calculated by assuming that the maximum filling $(h)$ is equal to the diameter of the pipe reservoir $\left(D_{a k}\right)$. Since the reservoir volume $(V)$ is a function of the reservoir length $\left(L_{z b}\right)$, which depends on the value of the parameter $C_{D}$, the differential equations (16) and (17) require an iterative solving.

\section{RESULTS}

The calculation of the detention reservoir storage volume involved adopting the triangular inflow hydrographs with volumes $V_{c}=900 \div 45,000 \mathrm{~m}^{3}$, maximum flow rate $I_{\max }=1.5 \div 7.5 \mathrm{~m}^{3} / \mathrm{s}$, the rise time $t_{p}=5 \div 150 \mathrm{~min}$; the values of the analysed hydrograph shape parameters $(\omega)$ ranged from 0.15 to 1.00 . The study analysed the diameters of orifices $D_{s p}=$ $=0.25 \div 1.25 \mathrm{~m}$ and the diameter of accumulation chambers $D_{a k}=1.25 \div 6.00 \mathrm{~m}$. Reservoir sizing was conducted for the set point values of the reduction coefficient $\beta=0.1 \div 0.9$. The analysis of such a significant variability range of the inflow hydrograph parameters and the tubular reservoir dimensions required over 1,000 simulations.

The conducted calculations provided a basis for the preparation of the nomograph (Fig. 3) showing the effect of the hydrograph shape parameter $(\omega)$ on the parameter $\kappa_{D}$, assuming the constant values of the maximum flow reduction coefficient $(\beta=0.1 \div 0.9)$.

On the basis of Figure 3 it can be said, that the relation $\kappa_{D}=f(\omega, \beta=$ const $)$ is the linear function of the formula:

$\kappa_{D}=\xi \cdot \omega+\varepsilon$

where:

$\xi, \varepsilon-$ empirical parameters characteristic of every value of the maximum flow reduction coefficient determined by the highest probability method.

The conducted calculations show the values of the coefficient of determinance $\left(\mathrm{R}^{2}\right)$ in equation $(26)$ for $\beta=0.1 \div 0.9$ vary from 0.989 to 0.996 when the variability illustrated in Figure 3 is extrapolated with a linear function.

Figure 3 shows that the higher the value of the hydrograph shape parameter $(\omega)$, the greater the parameter $\kappa_{D}$, assuming that $\beta=$ constans. For example, for $\beta=0.40$ and $\omega=0.30-\kappa_{D}$ value is 0.135 , 


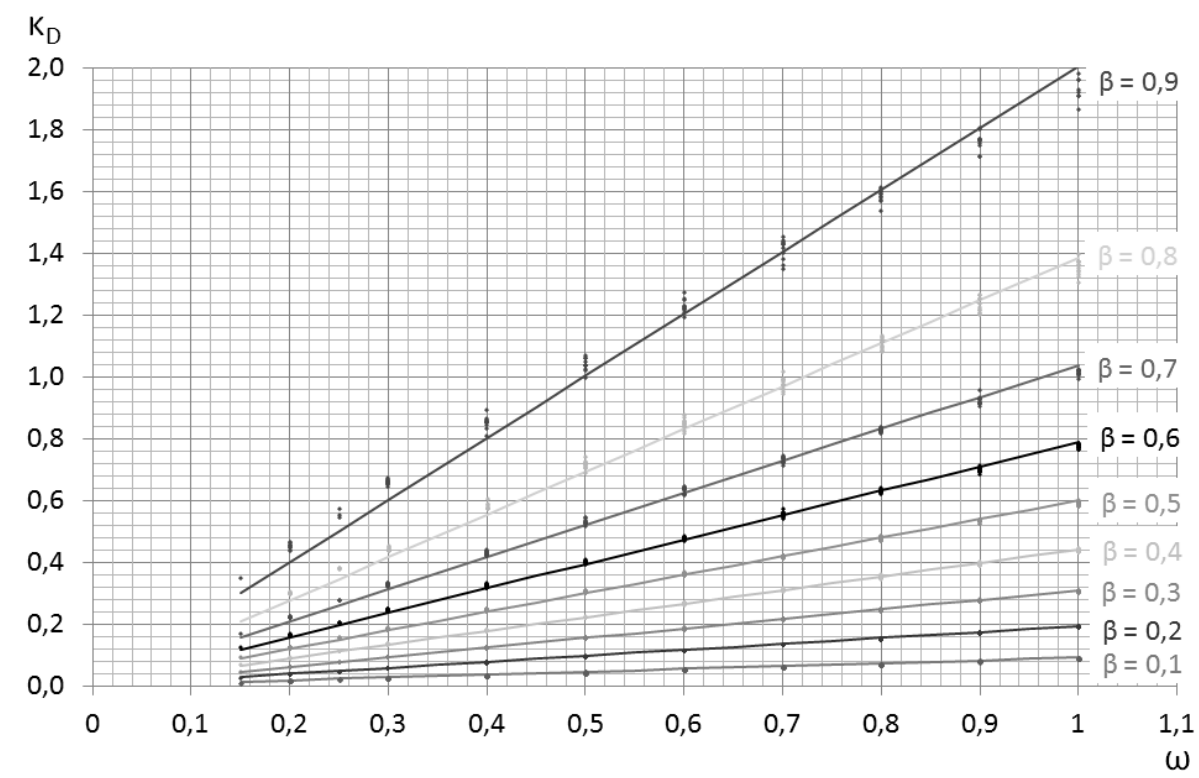

FIGURE 3 . The effect of the parameter $\kappa_{D}$ and the hydrograph asymmetry coefficient $(\omega)$ on the maximum flow reduction $(\beta)$; the points correspond to the values obtained from the simulation and the graphs of the curves result from equation (26)

and for $\omega=0.90-$ it is 0.390 . Moreover, the higher the maximum flow reduction coefficient, the higher the $\kappa_{D}$ values. For example, for $\omega=0.60$, with $\beta=0.40$ and $\beta=0.60$, the $\kappa_{D}$ values equal 0.268 and 0.483 respectively.

The analysis of the fitting of curves $\kappa_{D}=f(\omega)$ for different maximum flow reduction coefficients shows that as the $\beta$ value grows, the fitting of the design points for the curve defined with equation (26) becomes worse.

So far there have been no attempts at developing a graphical method of sizing a pipe reservoir, therefore it is not an easy task to compare the storage volumes obtained using this method with those obtained by other methods. In this case it is only possible to make a comparison with the methods which do not define precise requirements for the inflow hydrograph shape, the pipe reservoir cross section or the applied outlet control devices. In view of the above observations, it is reasonable to include Baker's method (1979) in the comparison, as well as the methods based on empirical equations $V_{z b} / V_{c}=$ $=f(\beta)$ included in the SCS method (1986). The analyses took into account the dimensionless volume of the pipe reservoir $\left(V_{z b} / V_{c}\right)$ obtained for $\omega=1.00$; this value yielded the greatest required volumes in the whole range of $\beta$. The results of the calculations are presented in Figure 4.

On the basis of Figure 4 it can be seen that the largest reservoir volume within the analysed methods is acquired from the nomograph obtained on the basis of the individual research project (Fig. 3) in 


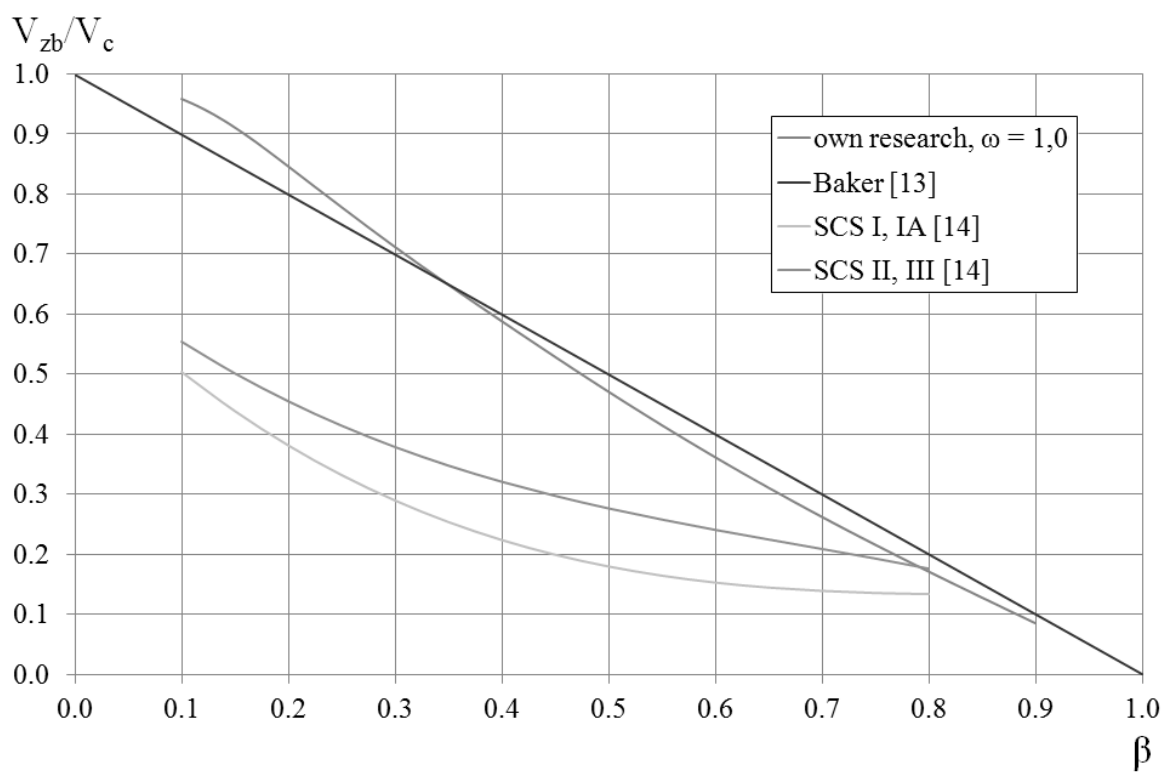

FIGURE 4. The comparison of the dimensionless volumes $\left(V_{z b} / V_{c}\right)$ of the storage reservoirs calculated by different methods for $\beta=0.1 \div 0.9$

the range of $\beta=0.10 \div 0.34$. In contrast, the reservoir volume determined by Baker's method is greater than $V_{z b}$ obtained from the graph $\kappa_{D}=f(\omega, \beta)$ in the range of $\beta=0.10 \div 0.80$. The reservoirs storage volume determined by the SCS (1986) and the Baker (1979) method for the precipitation of type I, IA, II and III are the smallest within the analyzed methods for $\beta=0.10 \div 0.80$.

Moreover, taking into account the variability of the $V_{z b} / V_{c}$ value obtained with the application of Baker's method as well as the developed nomograph (Fig. 4), it can be seen that the difference in the values of the storage volume obtained by using the discussed methods is the smallest for low and high values of the maximum flow reduction coefficient.

\section{EXAMPLARY APPLICATION OF THE GRAPHICAL METHOD OF SIZING PIPE RESERVOIRS}

In order to present the method described above for calculating the reservoir volume, an exemplary calculation was performed in which the diameter of the circular orifice and the volume of the reservoir $\left(V_{z b}\right)$ were calculated for the assumed maximum flow reduction coefficient $(\beta)$ and the diameter of the reser$\operatorname{voir}\left(D_{a k}\right)$.

The inflow hydrograph with the following parameters: the peak flow $\left(I_{\max }=\right.$ $\left.=3.00 \mathrm{~m}^{3} / \mathrm{s}\right)$, the rise time $\left(t_{p}=10 \mathrm{~min}\right)$, the hydrograph volume $\left(V_{c}=2,250 \mathrm{~m}^{3}\right)$ and the hydrograph shape parameter $\omega=0.80$ flows into the pipe reservoir diameter $\left(D_{a k}=4.00 \mathrm{~m}\right)$ and the diameter 
of the outlet pipe $\left(D_{s p}=0.50 \mathrm{~m}\right)$. The purpose is to calculate the maximum flow reduction coefficient $(\beta)$ as well as the reservoir length $\left(L_{z b}\right)$ and storage volume $\left(V_{z b}\right)$.

Substituting the appropriate data into equation (12) the following values were obtained: $\beta=\left[3.14 \cdot 0.25 \cdot(19.62)^{0.50}\right.$. $\cdot 0.52 \cdot 4.0 \cdot 0.5] / 3.0=0.35$; then $\kappa_{D}=$ $=0.30$ was read from the graph (Fig. 3). The length of the pipe reservoir $\left(L_{z b}\right)$ is calculated by transforming the formula (23) as follows:

$L_{z b}=\left[\frac{C_{s p} \cdot t_{p}}{D_{a k}^{0.21} \cdot V_{c}^{0.65} \cdot \kappa_{D}}\right]^{2.857}$

Substituting the numerical values, the $L_{z b}=80.25 \mathrm{~m}$ is obtained, and then the storage volume of the reservoir $V_{z b}=0.25$. $\cdot \pi \cdot D_{a k}{ }^{2} \cdot L_{z b}=0.25 \cdot 3.14 \cdot 4.0^{2} \cdot 80.25=$ $=1,007.94 \mathrm{~m}^{3}$.

\section{CONCLUSIONS}

The prepared nomograph $\kappa_{D}=f(\omega, \beta)$ shows that the hydrograph shape coefficient is a linear function of the $\kappa_{D}$ parameter provided $\beta=$ constans. The resulting parameter $\kappa_{D}$ was obtained by normalizing the differential equations for the volume balance, defining the pipe reservoir operation during the rise and recession phases. It takes into account the characteristics of the reservoir (the reservoir diameter, the orifice diameter and outflow coefficient) and the triangular inflow hydrograph parameters. The attached exemplary calculation proves that the reservoir sizing method, presented in the research paper, significantly simplifies its design process; it is unnecessary to use numerical methods in order to solve differentials equation for the water flow.

\section{REFERENCES}

AKAN O.A., 1990. Single outlet detention pond analysis and design. Journal Irrigation Drainage Engineering (ASCE), 116 (4), 527-536.

ALDRIGHETTI E., 2007. Computational hydraulic techniques for Saint Venant equations in arbitrarily shaped geometry $(\mathrm{PhD})$. Universatità Degli Studi di Trento.

ATV A - 118, 1990. Hydraulische Bemessung und Nachweis von Entwässerungssystemen.

ATV - Regelwerk, Arbeitsblatt A 118, Hennef.

BAKER W.R., 1979. Stormwater detention design for small drainage areas. Public Works, 108 (3), 75-79.

BASHA H.A., 1995. Routing equations for detention reservoirs. Journal Hydraulic Engineering, 121 (12), 885-888.

BURTON K.R., 1980. Stormwater detention basin sizing. Journal Hydraulics Division, 106 (3), 437-439.

CURREY D.L., AKAN O.A., 1998. Single outlet detention pond design and analysis equation. In: S.R. Abt ed. 1th International Water Resources, Memphis, 796-801.

DAYARANTE S.T., Perera B.J.C., 2004. Calibration of urban stormwater drainage models using hydrograph modelling. Urban Water Journal, 1 (4), 283-297.

DAYARANTE S.T., PERERA B.J.C., 2008. Regionalisation of impervious area parameters of urban drainage models. $U r-$ ban Water Journal, 5 (3), 231-246.

DONAHUE R.J., MCCUEN R.H., 1981. Comparison of detention basin planning and design models. Journal Water Resources Planning Management Division, 107 (2), 385-400. 
GIRONÀS J., NIEMANN J., ROESNER L.A., RODRIGUEZ F., ANDRIEU H., 2009. A morpho-climatic instantaneous unit hydrograph model for urban catchments based on the kinematics wave approximation. Journal of Hydrology, 377 (3-4), 317-334.

GOMEZ M., VASQUEZ S., SANCHEZ H., 2001. Pre-sizing of detention basins. 4th International Conference NOVATECH - Innovative technologies in urban drainage, 25-27 July 2001, Lyon, 555-562.

GRABER D.S., 2009. Generalized numerical solution for detention basin design. Journal Irrigation Drainage Engineering (ASCE), 135 (4), 487.

GUO J.C.Y., 1999. Detention basin sizing for small urban catchments. Journal of Water Resources Planning and Management (ASCE), 125 (6), 380-382.

GUO J.C.Y., 2004. Hydrology-based approach to storm water detention basin design using new routing schemes. Journal of Hydrologic Engineering, 9 (4), 333-336.

HAGER W.H., 2010. Wastewater Hydraulics. Theory and Practice. Second Edition. Springer - Verlag Berlin Heidelberg.

HONG Y.M., 2009. Graphical estimation of detention pond volume for rainfall of short duration. Journal of Hydro-environment Research, 2 (2), 109-117.

HONG Y.M., YEH N., CHEN J.Y., 2006. The simplified methods of evaluating detention storage volume for small catchment. Ecological Engineering, 26 (4), 355-364.

KESSLER A., DISKIN M.H., 1991. The efficiency function of detention reservoirs in urban drainage systems. Water Resources Research, 27 (3), 253-258.

KISIEL A., KISIEL J., MALMUR R., MROWIEC M. 2008. Retention tanks as key elements modern drainage systems. Technical Journal. Environment, 105 (1), 41-63.
McENROE B.M., 1992. Sizing Stormwater Detention Reservoirs to Reduce Peak Flows. Journal of Hydraulic Engineering, 120 (1), 1540-1549.

MROWIEC M., 2002. A tubular tank for stormwater storage in the stormwater collection system. Gas, Water and Sanitary Engineering, (7), 236-239 (in Polish).

MROWIEC M., 2007. Hydrodynamics modelling of tabular detention reservoirs using SWMM 5. Polish Journal Environment Studies, 1 (2A), 801-805.

NELDER J.A., MEAD R., 1965. A simplex method for function minimization. Computer Journal, 7, 308-313.

OSUCH-PAJDZIŃSKA E., ZAWILSKI M., 1998a. Model for Storm Sewer Discharge. I. Description. Journal Environment Engineering, 124 (7), 593-599.

OSUCH-PAJDZIŃSKA E., ZAWILSKI M., 1998b. Model for Storm Sewer Discharge. II. Calibration and Verification. Journal Environment Engineering, 124 (7), 600-611.

SHUSTER W.D., BONTA J., THURSTON H., WARNEMUENDE E., SMITH D.R., 2005. Impacts of impervious surface on watershed hydrology: A review. Urban Water Journal, 2 (4), 263-275.

SIKORSKA A., BANASIK K., 2010. Parameter identification of a conceptual rainfallrunoff model for a small urban catchment. Ann. Warsaw Agricult. Univ. - SGGW, Land Reclam., 42 (2), 279-293.

Soil Conservation Service SCS, 1986. Urban Hydrology for Small Watersheds. Second ed. U.S. Department of Agriculture, Washington, D.C., 6-4.

SZYDŁOWSKI M., MICHALIŃSKA-MURAWSKA J., 2012. Numerical simulation of transient flow in storm sewer using standard and improved McCormak scheme. Task Quarterly, 16 (1), 53-74.

VENUTELLI M., 2004. Direct integration of the equation of gradually varied flow. Journal Irrigation Drainage Engineering (ASCE), 130 (1), 88-91. 
Streszczenie: Graficzna metoda wymiarowania zbiornika rurowego dla krótkotrwatych, intensywnych opadów. Wymiarowanie zbiornika retencyjnego $\mathrm{w}$ celu zredukowania maksymalnych odpływów z kanalizacji deszczowej jest jednym $\mathrm{z}$ podstawowych zagadnień $\mathrm{w}$ inżynierii wodnej i lądowej. W artykule zaprezentowano metody wyznaczania optymalnej pojemności zbiornika rurowego. Zastosowanie uproszczonego modelu przepływu pozwoliło na powiązanie parametrów zbiornika rurowego (średnica komory akumulacyjnej, średnica otworu spustowego i współczynnik wydatku) i hydrogramu dopływu (czas przyboru, przepływ maksymalny podczas kulminacji, objętość fali, współczynnik asymetrii fali). $\mathrm{Na}$ podstawie uzyskanej zależności funkcyjnej sporządzono nomogramy pozwalające określić wymiary zbiornika i zapewnić redukcję przepły- wu maksymalnego na dopływie. Wykorzystanie zaproponowanej metodologii przedstawiono na prostym przykładzie obliczeniowym.

Stowa kluczowe: krótkie, intensywne opady, zbiornik rurowy, pojemność zbiornika, system odwodnienia liniowego

MS. received August 2014

\section{Author's address:}

Bartosz Szelag

Politechnika Swiętokrzyska

Wydział Inżynierii Środowiska, Geomatyki

i Energetyki

al. Tysiąclecia Państwa Polskiego 7

25-314 Kielce

Poland

e-mail: bartoszszelag@op.pl 